\title{
A Study on Non-Contact Games and Their Applicability during the Covid-19 Pandemic
}

\author{
Sümeyra Akkaya, Inonu University, Faculty of Education, 0000-0002-9942-9848
}

\begin{abstract}
In this research, it is aimed to examine non-contact games and their applicability during the Covid-19 Pandemic Period. Twenty classroom teachers, six male and fourteen female, participated in the research voluntarily. The research was carried out with the case study method, one of the qualitative research methods, and the data of the research were analyzed using the content analysis method. As a result of the study, it is seen that the views of the teachers on non-contact games are under nine categories, their views on the effects of non-contact games are under two categories, and their views on their practices to include non-contact games in their classrooms are under six categories. In the relevant literature, no study has been found on non-contact games. In line with the results of the research, the following recommendations can be made. Educating parents about the importance of non-contact play, providing inservice training to teachers about the distance education process, considering the Covid-19 pandemic and its effects.
\end{abstract}

Keywords: Non-contact games, Covid-19, Classroom teachers, Physical Education and Play Course
Inonu University Journal of the Faculty of Education

Vol 22, No 2, 2021

pp. 1806-1827

DOI:

10.17679/inuefd.980224

Article type:

Research article

Received : 08.08.2021

Accepted : 30.08.2021

Suggested Citation

Akkaya, S. (2021). A study on non-contact games and their applicability during the covid-19 pandemic. Inonu University Journal of the Faculty of Education, 22(2), 1806-1827. DOI: 10.17679/inuefd.980224 


\section{Covid-19 Pandemisi Döneminde Temassız Oyunlar ve Uygulanabilirliklerine ilişskin Bir inceleme}

Sümeyra Akkaya, Inönü Üniversitesi, Eğitim Fakültesi, 0000-0002-9942-9848

Öz

Bu araştırmada Covid-19 Pandemisi döneminde temassız oyunlar ve uygulanabilirliklerine ilişkin inceleme yapılması amaçlanmıştır. Araştırmaya altı erkek, on dört kadın sınıf öğretmeni gönüllü olarak katılmıştır. Araştırma nitel araştırma yöntemlerinden durum çalışması ile gerçekleştirilmiştir. Araştırma verileri içerik analizi kullanılarak analiz edilmiştir. Araştırma sonucunda sınıf öğretmenlerinin temassız oyunlara ilişkin görüşleri teması dokuz kategori altında, temassız oyunların etkileri teması iki kategori altında, temassız oyunların gerçekleştirilebilme teması altı kategori altında ele alınmıştır. Araştırma sonuçları doğrultusunda, temassız oyunlar konusunda ebeveyn eğitimi, uzaktan eğitim sürecinde temassız oyunlarla ilgili öğretmenlere hizmet içi eğitimlerin verilmesi önerilebilir.

Anahtar Kelimeler: Temassız oyunlar, Covid-19, sınıf öğretmenleri, Beden Eğitimi ve Oyun dersi

İnönü Üniversitesi Eğitim Fakültesi Dergisi Cilt 22, Sayı 2, 2021 ss. $1806-1827$ DOI:

10.17679/inuefd. 980224

Makale türü:

Araştırma makalesi
Gönderim Tarihi :

08.08.2021

Kabul Tarihi :

30.08.2021

Önerilen Atıf

Akkaya, S. (2021). Covid-19 pandemisi döneminde temassız oyunlar ve uygulanabilirliklerine ilişkin bir inceleme, Inönü Üniversitesi Eğitim Fakültesi Dergisi,, 22(2), 1806-1827. DOI: 10.17679/inuefd.980224 


\section{A Study on Non-Contact Games and Their Applicability during the Covid-19 Pandemic}

Around the world, some public health organizations have issued strict guidelines to encourage exercise and reduce serious health problems. The choice of sports to promote lifelong physical activity is based on two assumptions: All children in most developed countries receive some form of primary and secondary education. Education, which means that most children can get physical education through the education system. Second, positive and negative behaviors can persist throughout the process. Time; however, tracking physical activity from elementary school to adulthood is more difficult. Except for an observational study, most current follow-up examinations of children and adults are based on reminders of children's physical activity by adults (Trudeau et al., 1999).

Physical inactivity is listed as the fourth leading cause of death in the world, and the international problem of children's physical activity is worrying. For children, the benefits of physical activity are well known; however, in England, only 21\% of boys aged 5 to 15 and $16 \%$ of girls do 60 minutes of moderate to vigorous physical activity a day. Public health interventions in schools are important because they can reach a large number of children, and elementary schools have an important opportunity to increase the number of children in the middle developmental period during high-intensity physical activities (such as rest, and physical education). Moderate to vigorous physical activity is considered a major public health problem; therefore, prolonging the time of active physical education is very important. Regular physical education classes have many benefits for the physical, mental and social health of young people. It is important to encourage young people to be moderately active for 60 minutes or more and exercise every day, but $80 \%$ of young people fail. Physical activity decreases with age, especially during adolescence. The impact of physical activity on daily life and health must be demonstrated. In order to improve our quality of life and become healthy people, we must live an active lifestyle. Children's physical activities in community projects often lead to a sedentary lifestyle (Brown et al., 2009; Lander et al., 2017; Powell et al., 2016; 
Savcı \& Aysan, 2017). In this context, it is very important to increase physical activities for primary school children to gain habits.

Although the ages have passed, the place and importance of the game has never changed for the child, and the game has always preserved its feature of being a fun and learning tool. The situation is the same in educational environments. Involving students in the learning process and motivating them can be easily achieved through game-based teaching. Play is the most basic learning tool for children, especially in the preschool period, which is called the magic years of life by scientists (Koçyiğit et al., 2007). The child learns about himself, life, the order in society and the outside world through play. Play is an indispensable activity for the child's biological development and adaptation to the world. Play activities carried out in the family and at school are extremely important for the development of the child (Ayan, 2020).

Although it seems quite safe for children not to play on the streets, the child who does not play is also at the risk of obesity by remaining inactive (Turan \& Çalışkan, 2015). While the game activity took place in the form of imitation of natural events in the past, today it takes place in a virtual world by using tools, such as computers, tablets and phones (Z. Hazar \& Hazar, 2017). Digital games are the most important entertainment tools of the new generation. In addition to the entertaining function, digital games have also started to be used in teaching activities. Today, the advancement of technology, the decrease in children's playgrounds on the streets and the insecurity of the streets, and the Covid-19 pandemic process, the interest and expectations of the new generation have increased the orientation towards digital game-based teaching at home and school. In order to enable children to move, the amount of physical activity should be increased by sports scientists and experts in the preschool and primary school period. In the early childhood period, it is necessary for students to participate in regular and planned activities that are suitable for the characteristics of the age group, and carried out under the supervision of experts, and sports should be popularized with 
different games and entertaining equipment (Yavuz et al., 2019). Personal hygiene is acquired according to person's beliefs, values and habits. It is affected by cultural, social and familial factors as well as person's education. Sports activities are also one of the practices affecting hygiene habits. The affluents gather on the skin which gets dirty very quickly (Pepe et al., 2012).

For children born in and after 2000, expressions such as "Generation Z", "Digital Generation", "Digital Natives" have begun to be used due to the developments in technology and the adaptation of children to this age (Söğüt, 2020). This generation, which is known by different names, is interacting more and more with the digital world every day. Thanks to the ease of access to technology, there are devices, such as computers, phones, tablets in every home. Furthermore, almost every adult, and children in the younger age group think of these tools as tools that have always been present and used in daily life, not an innovation in their lives. Due to the ease of access and the intensity of use in daily life, the age of use of these tools is gradually decreasing (Orman \& Arıcak, 2019).

Individuals meet many of their needs other than their physiological needs from this world, and their interests and wishes are shaped according to the digital world. In this regard, teachers need to update themselves, be as good digital users as the audience they address to and integrate this into their teaching environments. Although the way children play games has changed with digitalization from the past to the present, the purpose of the game and its features such as entertainment and volunteering have not changed (M. Hazar et al., 2016). Likewise, although children tend towards different types of games, their interests and attitudes towards the game have never changed. It is an undeniable fact that technology has negative features as well as positive features. However, it is in the hands of educators to constantly express and complain about its negative effects, to turn the crisis into an opportunity instead of isolating the child from technology, and to use technology in favor of the child. For this, first of all, a good education strategy should be planned. In addition, 
educational environments should be designed according to the characteristics of the age and teachers should develop themselves in this direction. Otherwise, teachers will lag behind the age and their students and will lose their functions (Yüksel, 2019).

Game-based learning environments, which have always been preferred in teaching environments from past to present, are associated with Vygotsky's Social Constructivist learning theory as they reinterpret old knowledge for the child with new knowledge. Educational games are mostly preferred at primary school level, students take a more active role in the process and their imagination and synthesis skills are developed. Thanks to these games, previously learned information is reinforced and incorrectly learned information can be corrected (Öztürk, 2019). Digital games are very attractive activities for children due to the fact that preschool and primary school children need concrete data and materials, the colorful and fun figures that digital games offer to children, and the pleasure of spending time with these games. It has been seen that the Game-based learning approach, whose use dates back to the 1960s and is supported by technological developments, has many positive effects on the student's performance, attitude towards school and learning. In addition, it is known that educational digital games are effective on students' spatial skills, academic participation, attitudes towards collaborative learning, social skills, academic success and motivation (Altınpulluk, 2021). Developing students' strategy development, decision making, communication and attention skills through educational games, students have fun and interact with the environment (Erol et al., 2021). The use of games in education also has risky aspects for the student. If the readiness of the students is not sufficient, the use of games in learning environments may cause misconceptions (Zorlu \& Karamustafaoğlu, 2019). For this reason, there are points that teachers should pay attention to. In order to minimize the negativities that the teachers who will use the game in the teaching process may encounter and to maximize the efficiency to be obtained from this technique, the teacher should first make a 
good plan, and the games he chooses should be compatible with the outcome of the lesson (Genç Ersoy, 2021).

Although learning environments have changed, the game has always preserved its existence in these environments. With the game, the child learns without noticing. For this reason, the use of games in educational environments is a very effective method. Considering the developmental characteristics and attention span of primary school children, it is very important to place the game in education. From the outside, the game, which is seen as a distraction activity for the child, is actually a very serious business for the child. Because the child applies what he has learned in the real world in the game world, gains experience and discovers (Zorlu \& Karamustafaoğlu, 2019). Teaching with games, which is mostly preferred in classes with small age groups, increases the student's performance and positively affects his attitude towards education. The reason for this is that children of this age group learn concrete information more easily and comprehend difficult subjects more easily through games. In this research, it is aimed to examine non-contact games and their applicability during the Covid-19 Pandemic Period. In the study, it was tried to find answers to the following research questions.

What are the views of classroom teachers on the concept of non-contact play? What are the opinions of the classroom teachers about the aspects of the concept of non-contact play?

What are the views of classroom teachers on what can be done to support their students' playing non-contact games?

\section{Method}

Qualitative research approach was adopted in this study. The case study model, one of the qualitative research approaches, was used (Yıldırım \& Şimşek, 2018). After the literature review was conducted during the planning phase of the study, the application permission was obtained from Inonu University Social and Humanities Scientific Research Ethical Committee. The participants in the study were determined by using the criterion sampling method, one of 
the purposive sampling methods. The criterion used in the criterion sampling method is that the participating teachers provide distance education and voluntarily participate in the research in the 2020-2021 academic year. Twenty classroom teachers, six male and fourteen female, participated in the research study voluntarily. In order to interview teachers, semistructured interview forms containing questions about non-contact games were prepared, and then the forms were finalized by taking expert opinions from one academic who has PhD in Assessment and Evaluation, three academics who have PhDs in Primary School Teaching and one Physical Education and Sports expert. Following the expert opinions, the forms were made ready for interview. Interviews were conducted with teachers face-to-face. Participants participated voluntarily, data began to be collected after obtaining the necessary permits, first by correspondence with school officials for access to teachers, then by the teacher. Volunteers are contacted and interviewed. In terms of pandemic preparedness, most interviews are conducted using telephone or video applications. The interview duration was 10 to 15 minutes and was approved by the study ethics committee. After the interviews, it was converted into text and transferred to the computer environment. The details collected from the interviews were transcribed by the researcher. To the transcribed texts were placed in parentheses while direct quotes were given. Afterwards, the data were analyzed by the researcher, and another expert coded the data to ensure the inter-coder reliability. The themes and categories created as a result of the analysis were explained in the findings, and the study was reported.

For the internal validity of the study, the opinions of the students were given with direct quotations. In order to determine the reliability of the data analysis, the reliability value was calculated with the formula proposed by Miles and Huberman (1994). In qualitative studies, the concordance between coders should be at least $85 \%$ (Miles, Huberman and Saldana, 2014, p.79). In the current study, the inter-coder reliability index is found as .92 with the help of the Cohen Kappa formula. 


\section{Findings}

\section{Findings on the Opinions of Classroom Teachers About Non-Contact Games}

\section{Table 1}

Opinions of Classroom Teachers About Non-Contact Games Theme

\begin{tabular}{ll}
\hline Categories & $\mathbf{f}$ \\
\hline Non-contact physically & 15 \\
Social distance & 6 \\
Non-contact objects & 4 \\
Covid-19 precautions & 4 \\
Educational games & 4 \\
Having fun & 3 \\
Providing socialization & 2 \\
Verbal games & 1 \\
Face to face education & 40 \\
\hline
\end{tabular}

As can be seen in Table 1, the opinions of the teachers were grouped under nine categories. These are; non-contact physically $(f=15)$, social distance $(f=6)$, non-contact objects $(f=4)$, Covid-19 precautions $(f=4)$, educational games $(f=4)$, having fun $(f=3)$, providing socialization $(f=2)$, verbal games $(f=1)$ and face to face education $(f=1)$.

Teacher 1. "It is a game style that I know came into our lives with the Covid-19 pandemic, where social distance is maintained. It is aimed to ensure the socialization of the students to some extent with these games played by following the social distance and hygiene rules." 
Teacher 3. "These are non-contact games created for students to participate in games and activities during the Covid-19 process."

Teacher 4. "All kinds of fun games and activities that children play by paying attention to social distance without touching each other."

Teacher 6. "It is a game in which children play without touching each other or a common object. "

Teacher 8. "These are the games that the players play without physically touching any person or object."

Teacher 9. "Within the scope of Covid-19 measures, it refers to the games played without contacting in order to both learn and teach the measures during face-to-face training."

Teacher 10. "Non-contact play is a type of game in which materials, such as balls and ropes are not used, in which contact is minimized or absent, which ensures the safe socialization of children in line with the health measures taken due to the Covid-19 pandemic. "

Teacher 11. "Play is the way how children perceive the world. It is their small living space and an opportunity for them to learn about the world. Games are sometimes played individually and sometimes in groups. Interpersonal interaction is very high in group games. However, the importance of social distance and mask rules has increased especially during the pandemic process, which has limited physical interaction among people. The importance of games in which physical interaction is limited, suitable for social distance, has increased for children. Such games are called Non-Contact Games. It is played with a certain group, and it hinders physical contact in accordance with social distance rules."

Teacher 12. "Verbal games without contact with an object or person."

Teacher 13. "All of the fun activities where children do not have physical contact while playing." 
Teacher 14. "The type of game in which students learn while having fun and protect their health while doing this."

Teacher 15. "Activities performed by individuals without contacting each other."

Teacher 16. "The game is a small reflection of real life to develop the child's life skills. Thanks to games, social and physical interaction among children increases. In non-contact games, physical interaction is restricted as much as possible. It is ensured that the interaction between children is regulated in accordance with social distance. "

Teacher 18. "Educational games where social distance can be applied."

Teacher 19. "These are games that affect the mental and physical development of students positively but do not require contact."

Findings on the Opinions of Classroom Teachers About the Aspects of Non-Contact Games

Table 2

Opinions of Classroom Teachers About the Aspects of Non-Contact Games Theme

\begin{tabular}{ll}
\hline Categories & $\mathbf{f}$ \\
\hline Positive & 18 \\
Negative & 17 \\
Total & 35 \\
\hline
\end{tabular}

As can be seen in Table 2, the opinions of the teachers were grouped under two categories. These are; positive $(f=18)$ and negative aspects $(f=17)$. 
Positive aspects

Teacher 2. "Students are provided to play games in a safer environment during this pandemic."

Teacher 4. "Students can be given a sense of responsibility. He may learn to think about the health of others, too."

Teacher 5. "There may be materials that can be used individually, but I do not use the materials used in many games, because they require contact."

Teacher 6. "I think non-contact games increases creativity."

Teacher 8. "It can be positive in terms of developing language and speaking, comprehension-explanation, mental process skills, and cause-effect relationship skills. It can also develop social skills, such as practical and quick thinking, patience, respect, selfexpression in players."

Teacher 11. "Non-contact games develop children's empathy skills. They provide learning while having fun. They provide group dynamism. They increase mutual love and respect. They develop active listening skills. They increase comprehension and comprehension skills."

Teacher 12. "They do not need an object."

Teacher 13. "Language development in the child, self-expression features can develop better and prevent the transmission of infectious features, such as diseases. Inequalities due to physical conditions can be eliminated."

Teacher 16. "Non-contact games are of great importance in meeting the social needs of children when people should not come into contact, such as the pandemic process. It is also important in developing children's attention skills. Because the child should observe his friend well during the game. Finally, it can be played as an alternative to contact games." 
Teacher 19. "It is useful for the development of students and is suitable for mask, distance and hygiene rules."

Teacher 20. "Ensuring students have a good time during the pandemic process."

Negative aspects

Teacher 1. "Because of the use of masks, communication problems can occur when the mimics are not clear."

Teacher 2. "Elementary school students love to explore and learn how to weave materials. They like to be in contact with their friends. In this respect, non-contact games can be games that children do not want."

Teacher 3. "Not being able to play traditional and contact children's games and warning about constant contact in the process."

Teacher 5. "It negatively affects the social aspects of the students and reduces the group spirit."

Teacher 6. "I think it will make us forget our traditional games and create an insincere and selfish generation."

Teacher 7. "Inability to use games and materials that require contact."

Teacher 8. "There may be time problems due to delays in terms of perception. People with weak mental thinking skills may experience self-confidence problems."

Teacher 9. "It can reduce the time for students to bond."

Teacher 11. "It can provide individualization. It can increase the desire to play alone. Restricts physical intimacy between individuals."

Teacher 12. "Some students find it boring." 
Teacher 13. "It may cause distraction in the child or may not provide the mobility necessary for physical development."

Teacher 14. "Making socialization difficult."

Teacher 15. "Because students can't touch each other..."

Teacher 16. "Some children can learn better by touching. In this respect, non-contact games may not meet the expectations for such children."

Teacher 20. "Decreased communication and interaction of children."

Findings on the Opinions of Classroom Teachers on What Can Be Done to Support Their Students' Playing Non-Contact Games

Table 3

Opinions of Classroom Teachers on What Can be Done to Support Their Students' Playing Non-Contact Games Theme

\begin{tabular}{ll}
\hline Categories & $\mathbf{f}$ \\
\hline Informing & 7 \\
Game variation & 7 \\
Increasing the number of materials & 3 \\
Rewarding those who follow the rules & 2 \\
Teacher involvement & 1 \\
Parent education & 1 \\
Total & $\mathbf{2 1}$ \\
\hline
\end{tabular}


As can be seen in Table 3, the opinions of the teachers were grouped under 6 categories. These are informing $(f=7)$, game variation $(f=7)$, increasing the number of materials $(f=3)$, rewarding those who follow the rules $(f=2)$, teacher involvement $(f=1)$ and parent education $(f=1)$.

Teacher 2. "The variety of games can be increased. The game can be adapted to the pandemic conditions by making minor changes in the contact rules of the games they want."

Teacher 3. "Games can be created where they can be more easily involved in the process."

Teacher 4. "Students need to be made aware. The student who knows why he should play these games is more careful and attentive. It is necessary to communicate with the parents and ensure that they give the necessary information to their children. Otherwise, since the student who obeys the rules at school does not comply with the rules outside of school, it is not enough just to obey the rules during school hours."

Teacher 5. "Sometimes the games can be made fun by doing some alterations. By increasing the number of games, we can ensure that students have more choice rights. Information should be given about why these games should be preferred by giving information in terms of health."

Teacher 6. "No matter how much we direct students to non-contact games in schools, they will play the games they want on the street where their houses are located. Instead of raising generations who obey the rules only when there are supervisors near them, we should make them understand the rules and want to act in accordance with them. The education of adults who will set an example for them should not be forgotten. From another point of view, various educational non-contact games can be played and traditionalized in schools on weekends and summer holidays."

Teacher 8. "The learners an get used to it by using non-contact games to reinforce the at the end of the lesson. The desire to play can be aroused by showing different games. Time can be spared to meet in games in virtual environments." 
Teacher 9. "By showing differences in the venue, material and music choices accompanying the play, students can be prevented from getting bored and become more willing."

Teacher 10. "Materials can be offered. Face-to-face games and physical activities class hours can be given."

Teacher 11. "Thanks to non-contact games, they should be made to realize how well they have fun by following the rules. The advantages of non-contact games should also be mentioned."

Teacher 15. "Non-contact games that students like can be played. Students should be reminded from time to time that the corona virus disease continues and what the consequences are, and it is expressed to students that non-contact games will be appropriate during the pandemic period."

Teacher 16. "Students can be shown a variety of non-contact games so that they can choose what they love and like about these games."

Teacher 17. "Sufficient information can be provided. (on why we play non-contact games) Alternative game ideas can be offered."

Teacher 18. "Games that combine multiple games using interesting materials can be compiled."

\section{Discussion, Conclusion \& Recomendations}

As a result of the current research study, it is seen that the views of the teachers on non-contact games are under nine categories, their views on the effects of non-contact games are under two categories, and their views on their practices to include non-contact games in their classrooms are under six categories. In line with the results of the research, the following recommendations can be made. When the relevant literature was examined, no publication was found about non-contact games(Altun, 2016; Ataş, 2015; Aydemir, 2021; Aydeniz, 2019; Bayat et al., 2016; Bozdemir et al., 2015; Can Ceylan, 2015; Can Ceylan \& Dalaman, 2017; Can 
\& Çava, 2018; Celayir, 2015; Dalaman, 2010; Ertan, 2013; Güven \& Yıldız, 2014; Kazu \& Aslan, 2014; Kılıç, 2014; Mısır, 2018; Özkan Navdar, 2017; Özyürek \& Çavuş, 2016; Şentürk et al., 2015; Temel, 2018; Yılmaz, 2020; Yürek, 2017). Non-contact games are diversified in four categories under the title of meeting, communication, movement and cooperation in the Noncontact Games book of the Ministry of National Education (Erdoğan \& Erdoğan, 2020).

In the research conducted to determine the problems faced by classroom teachers in physical education lessons according to their variables, it was determined that classroom teachers had some professional problems in terms of practice, physical conditions, formation dimensions and caring about physical education lessons. Inadequate and incomplete facilities, tools and equipment related to the physical education lesson in schools, the knowledge and formation competencies of the classroom teachers about the physical education lesson cause problems in terms of the processing and efficiency of the lesson, and the application and care problems arising from these situations were determined to be some of the problems identified (Bozdemir et al., 2015).

In another study conducted with classroom teachers, classroom teachers exemplified game-based learning as e-learning activities, creative drama activities, digital games, values education and character education. Regarding game-based learning, teachers have experienced problems such as time scheduling, students' uncooperative behavior, teachers' inadequate infrastructure in organizing and designing games, economic problems, and technical barriers. The use of games in lessons encourages reflection and understanding of learning. Game-based learning helps students develop problem-solving skills and enables them to interpret their society, nature and the world around them through experiences. Games provide information in a relevant context or setting. For this reason, social studies lessons, which aim to educate students as active members of a class, are very important for classroom leisure time activities, games and physical activities (Ucus, 2015). 
In a study on game teaching, all of the teachers who participated in the study emphasized that it is necessary to use the game in teaching and that learning becomes fun and permanent, especially thanks to the game. It has been determined that the teachers who use the game as a teaching method mostly use the game in the teaching of mental complex and mathematical subjects (Özyürek \& Çavuş, 2016).

In a study about the game and physical activities lesson, the majority of the classroom teachers emphasized that the game and physical activities lesson is an important lesson in the primary school stage and it is important for the development of the child's health. The majority of the teachers stated that the game and physical activities lesson was done regularly, and the intensity of the other lessons did not affect their ability to do the game and physical activities lesson (Can Ceylan \& Dalaman, 2017).

In another study about the game and physical activities lesson, it was determined that the classroom teachers could not perform the game and physical activities lessons at a sufficient level due to the lack of sports facilities and equipment, the problems in the applicability of the physical education program, and the lack of knowledge and equipment of the classroom teachers about the game and physical activities lessons. . The lack of knowledge and equipment of the classroom teachers about the game and physical activities course affects their ability to process these lessons efficiently, and therefore, they have to train in mathematics, Turkish, etc., which are considered important in this course. It was determined that they did the lessons (Güven \& Yıldız, 2014).

Educating parents about the importance of non-contact play, providing in-service training to teachers about the distance education process, considering the Covid-19 pandemic and its effects, it can be suggested that non-contact playgrounds be created in schoolyards for students and students should be given the opportunity to play in these areas in schoolyards close to them. 


\section{Conflict of Interest Statement}

The author declared no potential conflicts of interest regarding the research, authorship and/or publication of this article.

\section{Ethical Committee Decision}

Ethical permission was obtained from the 2021/8-45 Inonu University Social and Humanities Scientific Research Ethical Committee for this research. 


\section{References}

Altınpulluk, H. (2021). Video oyunların eğitim araştırmalarında kullanımı: Bir sistematik tarama. Anadolu Üniversitesi Sosyal Bilimler Dergisi, 21(1), 185-212.

Altun, M. (2016). Ilkokul oyun ve fiziki etkinlikler dersi yeni öğretim programının sınıf öğretmenlerinin görüşleriyle değerlendirilmesi: Kırşehir ili örneği. Amasya Üniversitesi Eğitim Fakültesi Dergisi, 5(2), 327-347. https://doi.org/10.17539/aej.25944

Ataş, H. K. (2015). Türkiye'de beden eğitimi ve spor alanında 2004 - 2014 yılları arasında yapılmış yüksek lisans tezlerinin çeşitli değişkenler açısından incelenmesi. Abant İzzet Baysal Üniversitesi.

Ayan, S. (2020). Oyunla renklendir hayatı (S. Ayan, Ed.). Vizetek Yayıncılık.

Aydemir, B. (2021). Illköğretimde beden eğitimi ve oyun dersi öğretim programının uygulanabilme koşulları ile ilgili sını öğretmenlerinin görüşleri. Bartın Üniversitesi.

Aydeniz, G. (2019). Illkokullarda oyun temelli öğrenme yönteminin öğrencilerin okula bağlanma ve kural bilinci düzeyine etkisi. Ondokuz Mayıs Üniversitesi.

Bayat, S., Kaymak, M. N., \& Balcı, O. (2016). Primary teachers' opinions about the difficulties encountered in the play and physical activities course. Journal of Human Sciences, 13(3), 4917. Https://Doi.Org/10.14687/Jhs.V13i3.3906

Bozdemir, R., Çimen, Z., Kaya, M., \& Demir, O. (2015). Sınıf öğretmenlerinin beden eğitimi ve spor dersinde karşılaştıkları problemler (Tokat ilii Örneği). Uluslararası Türk Eğitim Bilimleri Dergisi, Ekim, 221-234.

Brown, W. H., Googe, H. S., Mciver, K. L., \& Rathel, J. M. (2009). Effects of teacher-encouraged physical activity on preschool playgrounds. Journal of Early Intervention, 31, 126-145. https://doi.org/10.1177/1053815109331858

Can Ceylan, G. (2015). ilkokul II. sınıf oyun ve fiziki etkinlikler dersi kazanımlarının gerçekleşme düzeyine ilişkin öğretmen görüşleri. Necmettin Erbakan Üniversitesi.

Can Ceylan, G., \& Dalaman, O. (2017). İlkokul 2. sınıf oyun ve fiziki etkinlikler dersi kazanımlarının gerçekleşme düzeyine ilişkin öğretmen görüşleri. Uluslararası Eğitim Bilimleri Dergisi, $4(10), 235-254$.

Can, S., \& Çava, G. (2018). Sınıf öğretmenlerinin görüşlerine göre ilkokulda uygulanan oyun ve fiziki etkinlikler dersinin değerlendirilmesi. Trakya Üniversitesi Eğitim Fakültesi Dergisi, 261-273. https://doi.org/10.24315/trkefd.318132

Celayir, i. (2015). illkokul programı oyun ve fiziki etkinlikler dersinin işlevselliğinin ve geleneksel çocuk oyunlarının uygulanabilirliliğine göre incelenmesi. Fırat Üniversitesi.

Dalaman, O. (2010). Ilköğretim birinci kademede beden eğitimi dersi öğretim programı kazanımlarının gerçekleşme durumuna ilişkin öğretmen görüşleri. Selçuk Üniversitesi.

Erdoğan, T. \& Erdoğan, Ö. (2020). Temassız oyunlar. Millî Eğitim Bakanlığı Yayınları.

Erol, S., Erdem, I., \& Akkaya, A. (2021). Yabancı dil olarak türkçe öğretiminde eğitsel oyunların kullanımının akademik başarı, tutum ve kalıcılığa etkisi. Bayburt Eğitim Fakültesi Dergisi, 16, 166-183. https://doi.org/10.35675/befdergi.850249

Ertan, A. (2013). Ilkokul birinci sınıflarda oyun ve fiziksel etkinlikler dersi kazanımlarının amaca ulaşabilirliğinin değerlendirilmesi. Celal Bayar Üniversitesi.

Genç Ersoy, B. (2021). Türkçe öğretiminde eğitsel oyun kullanımı: Bir meta-tematik analiz çalışması. Ana Dili Eğitimi Dergisi, 9(2), 510-530. 
Güven, Ö., \& Yıldız, Ö. (2014). Sınıf öğretmenlerinin oyun ve fizikî etkinlikler dersinden beklentileri. Kastamonu Education Journal, 22(2).

Hazar, M., Altun, M., \& Hazar, Z. (2016). 6-14 yaş çocukların dijital oyun oynamalarına ilişkin ebeveyn görüşleri (Nitel bir araştırma). Uluslararası Hakemli iletişim ve Edebiyat Araştırmaları Dergisi, 12, 40-67. https://doi.org/10.17361/uhive.20161222013

Hazar, Z., \& Hazar, M. (2017). Çocuklar için dijital oyun bağımlılı̆ı ölçeği. Journal of Human Sciences, 14(1), 203-216. https://doi.org/10.14687/jhs.v14i1.4387

Kazu, H., \& Aslan, S. (2014). Oyun ve fiziki etkinlikler dersinin birinci sınıf öğretmenlerinin görüşlerine göre değerlendirilmesi (Elazı̆̆ ili örneği). Fırat Üniversitesi Sosyal Bilimler Dergisi, 24(1), 49-63.

Kılıç, M. (2014). Ilkokul beden eğitimi ve spor dersi programının sınıf öğretmenleri ve beden eğitimi öğretmenleri tarafından değerlendirilmesi: Sahinbey Gaziantep örneği. Zirve Üniversitesi.

Koçyiğit, S., Tuğluk, M. N., \& Kök, M. (2007). Çocuğun gelişim sürecinde eğitsel bir etkinlik olarak oyun. Atatürk Üniversitesi Kazım Karabekir Eğitim Fakültesi Dergisi, 16, 324-342. https://dergipark.org.tr/tr/pub/ataunikkefd/issue/2777/37245\%0A

Lander, N., Eather, N., Philip, •, Morgan, J., Salmon, J., \& Barnett, L. M. (2017). Characteristics of teacher training in school-based physical education interventions to improve fundamental movement skills and/or physical activity: A systematic review. Sports Medicine, 47, 135-161. https://doi.org/10.1007/s40279-016-0561-6

Mısır, E. (2018). Türkiye'de beden eğitimi alanında yapılan doktora tezlerinin incelenmesi. Bolu Abant İzzet Baysal Üniversitesi.

Miles, M. B., \& Huberman, A. M. (1994). Qualitative data analysis: An expanded sourcebook (Second ed.). Sage Publications.

Miles, M. B., Huberman, A. M. \& Saldana, J. (2014). Qualitative data analysis: A methods source book. Sage Publications.

Orman, N. K., \& Arıcak, O. T. (2019). Aşırı dijital oyun oynama davranışında anne tutumu ve benlik kontrolünün etkisi. Cyprus Turkish Journal of Psychiatry and Psychology, 1(1), 40-42. https://doi.org/10.35365/ctjpp.19.special1.11

Özkan Navdar, A. (2017). Sınıf öğretmenlerinin oyun ve fiziki etkinlikler dersinin öğretim süreciyle ilgili görüşleri (Rize Ili Örneği). Recep Tayyip Erdoğan Üniversitesi.

Öztürk, G. (2019). Fen metinleri destekli dijital oyun ile fen öğretiminin öğrencilerin akademik başarı ve bilgisayar kullanmaya yönelik tutumuna etkisi. Muğla Sıtkı Koçman Üniversitesi, Muğla.

Özyürek, A., \& Çavuş, Z. S. (2016). illkokul öğretmenlerinin oyunu öğretim yöntemi olarak kullanma durumlarının incelenmesi. Kastamonu Education Journal, 24(5), 2157-2166.

Pepe, K., Kara, D., Konar, N. \& Vardar, T. (2012). Investigation of the individual hygiene routine and self care methods of sportsmen. Nigde University Journal of Physical Education And Sport Sciences Vol 6, No 1, 42-55.

Powell, E., Woodfield, L. A., \& Nevill, A. M. (2016). Increasing physical activity levels in primary school physical education: The SHARP Principles Model. Preventive Medicine Reports, 3 , 7-13. https://doi.org/10.1016/J.PMEDR.2015.11.007

Savcı, M., \& Aysan, F. (2017). Teknolojik bağımlııılar ve sosyal bağlılık: internet bağımlılı̆̆ı, sosyal medya bağımlılığı, dijital oyun bağımlılığı ve akıllı telefon bağımlılığının sosyal bağlılığı 
yordayıcı etkisi. Dusunen Adam, 30(3), 202-216.

https://doi.org/10.5350/DAJPN2017300304

Sögüt, F. (2020). Dijital ebeveynlerin dijital oyunlar ve şiddet ilişkisine yönelik algıları. iletişsim Kuram ve Araştırma Dergisi, 51, 79-100.

Şentürk, U., Yılmaz, A., \& Gönener, U. (2015). Sınıf öğretmenlerinin oyun ve fiziki etkinlikler dersi ile ilgili görüş ve uygulamaları. Spor Yönetimi ve Bilgi Teknolojileri Dergisi, 10(2).

Temel, A. (2018). Illkokul, oyun ve fiziki etkinlikler dersi öğretim programı kazanımlarının gerçekleşmesine ilişkin öğretmen görüşleri. Cumhuriyet Üniversitesi.

Trudeau, F., Laurencelle, L., Tremblay, J., Rajic, M., \& Shephard, R. J. (1999). Daily primary school physical education: Effects on physical activity during adult life. Medicine and Science in Sports and Exercise, 31(1), 111-117. https://doi.org/10.1097/00005768-19990100000018

Turan, M. \& Çalışkan, E. F. (2015). Organik oyunlar ve organik oyun alanları. Bartın Üniversitesi Eğitim Fakültesi Dergisi, XIV. Uluslararası Katılımlı Sınıf Öğretmenliği Eğitimi Sempozyumu (21-23 Mayıs 2015) Özel Sayısı, 91 - 96.

Ucus, S. (2015). Elementary school teachers' views on game-based learning as a teaching method. Procedia - Social and Behavioral Sciences, 186, 401-409.

Https://Doi.Org/10.1016/J.Sbspro.2015.04.216

Yavuz, A., Özudoğru, E. \& Çelik Kayapınar, F. (2019). Physical education and game education in preschool and primary school. Journal of Physical Education and Sport Studies, 11(2); 130 138.

Yıldırım, A., \& Şimşek, H. (2018). Sosyal bilimlerde nitel araştırma yöntemleri. Seçkin Yayıncılık.

Yılmaz, M. (2020). Sınıf öğretmenlerinin beden eğitimi ve oyun dersinin uygulanmasında yaşadığı sorunlar ve çözüm önerileri. Amasya Üniversitesi.

Yüksel, H. (2019). Türkçe dersinde kullanılan eğitsel dijital oyunların ders başarısı ve motivasyona etkisi. Bülent Ecevit Üniversitesi.

Yürek, Y. (2017). 4+4+4 eğitim sisteminde ilkokul 1.,2.,3.,4. sınıflarda beden eğitimi ve spor uygulamalarına ilişkin yönetici ve öğretmen görüşleri. Marmara Üniversitesi.

Zorlu, A., \& Karamustafaoğlu, O. (2019). Fen öğretimine yönelik tasarlanan bir eğitsel oyun: Döngüyü tamamla. Ondokuz Mayıs Üniversitesi Uluslararası 100. Yıl Eğitim Sempozyumu, 50-62.

Correspondence

Asist. Prof. Dr. Sümeyra AKKAYA sumeyra.akkaya@inonu.edu.tr 